\title{
Teaching Critical Thinking as a Discipline
}

\section{EUGENE GARVER}

Saint John's University, by creating North America's first endowed Chair in Critical Thinking, has confronted me with a couple of unique opportunities. First, the University wisely did not place the Chair in any department, and I am consequently presented with the chance to think about critical thinking independent of considerations of academic turf and FTE. This is such an unusual opportunity that whatever critical thinking might turn out to be when one may ignore those vulgar considerations might have quite limited relevance to the work of critical thinking in other circumstances; at least, though, those who carry on in less ideal situations will be able to cast their arguments in terms of political necessity rather than intellectual justification. Second, I have the challenge of trying to insure that this critical thinking program not go away-leaving only the low-level skills equivalent to remedial writing - when all the national attention, energy, intelligence, and money go to on the next fashion; I hope Saint John's will become a place where a flourishing program exists in which faculty interests in teaching and in scholarship can come together in critical thinking. This latter is a challenge I think everyone committed to teaching critical thinking shares, although there is obviously enough diversity in interpretation that your ideal of liberal education looks just like my nightmare of remedial or mechanical instruction. In my judgment, the challenge is to "thicken" critical thinking from a skill to a discipline, requiring commitment to a subject-matter rather than independence of all subjects, a discipline in which we all, students, faculty qua teachers, faculty qua scholars, participate and grapple with analogous problems. In planning my own courses, and in experimenting with different kinds of faculty development, I have been guided by a conception of critical
Saint John's University

thinking suggested by the following three lines of argument. To use rather than mention these lines of argument would require a different, and far more extended, treatment that 1 cannot undertake here. I hope, though, that this sketch will be sufficient to invite some counterargument.

1. A non-controversial and brief way of describing critical thinking is attentiveness to the formal aspects of thinking. Making the idea of form more precise can be done in a variety of ways, each of which can be the basis for a different possible approach to critical thinking, but awareness of an articulation of the formal dimensions of thought must be fundamental. The most popular resources for talking about the formal side of thinking, modern mathematical logic and cognitive psychology, are, unfortunately, not especially well suited for exposing and articulating the structure of natural and practical thinking, precisely because they represent form as indifferent to subject-matter, a relation of form and matter that 1 think undermines the potential autonomy of critical thinking. Those conceptions of form make the complexities of natural, practical argument into an inconvenience rather than an inevitable, and often desirable, feature of deliberation and inquiry. Everyone admits that there is no single schema that adequately captures all acts of thought. Taking that truism more seriously, however, would require that we think about the use of multiple methods for representing arguments as somehow more than additive - as in the sentiment that since no one scheme gets at everything important about every argument, the more the better-or tactical-as in a decision that this argument seems to be one that calls for formalization by predicate calculus.

Consequently one way of giving depth to the activities of critical think- 
ing - and thereby preventing bowing to either remedial or political pressures - is by looking at alternative ways of capturing intellectual and discursive forms and structures, ways that connect form and content more usefully. I have in mind readings such as Bacon's New Organon, Newman's Grammar of Assent, and Aristotle's Rhetoric; more generally, I propose that critical thinking requires a research project of exploring ways of thinking about discursive and intel. lectual form that range over the history of alternative theories of logic, rhetoric, and literary form. Logic has a history well worth recovering, and texts such as the ones I listed are useful occasions for meditation on the significance of the profound truth that actual thinking is resistant to complete codification by any conception of method, and give some reason to think that that recalcitrance should not be reason for regret.

2. Critical thinking needs something to think about. Any method is intelligible only relative to some manifold; put more pragmatically, the test of any proposed method for treating intellectual form is its employment in confronting a difficult text. I believe that a crucial aspect of the enterprise of keeping critical thinking from becoming remedial, of making critical thinking into a discipline with its own integrity and intellectual respectability (not to mention respectability within the aca demy) is the appropriation of a canon for critical thinking coordinate with its methods. If what counts as good method in critical thinking varies with the sorts of materials under examination, then the way to keep the exploration of techniques and devices from degenerating into a technology and a remedial skill is by constantly testing the techniques against canonical readings; there's something wrong with a method that works for newspaper editorials but cannot handle Lincoln's Second Inaugural Address.

A canon for critical thinking provides a constant test for proposed methods; in addition such texts have a richness that resists reduction to any theory, transforming the enterprise of theory building into a more permanent one, and not something to be accomplished, and once accomplished, finished. A canon of texts of independent value is a crucial feature of any discipline that wants to encourage debate as a permanent feature of its intellectual life, because it permits pluralism and without degenerating into mere discord. I see the field of argumentative literature as constituting the appropriate subject-matter for critical thinking; there is a large body of acknowledged great works that other parts of the humanities, such as philosophy and literature departments, have trouble accommodating, and it is those that critical thinking ought to be concerned with.

Think of the following texts, all of which seem to me to be things that we all wish our students would read, but which rarely get taught because no discipline owns them: Cicero, de Natura Deorum, Augustine, Confessions, Machiavelli, Prince, Luther, De Servo Arbitrio, Erasmus, Diatribe, Montaigne, Essays, Bacon, Essays, Pascal, Pensees, Rousseau, Discourses, Swift, Gulliver's Travels, Smith, Wealth of Nations, Madison et al., Federalist Papers, Notes on the Convention.

My canon for critical thinking is not generated by default, and it is no accident that these sorts of works do not fit comfortably within the bounds of departments currently constituted. Just what they have in common, though, is another story. A canon is not the same as a subject-matter, and it would take more than pure induction to move from this list of books to a subject-matter for critical thinking to be about. But that's work that cannot be summarized here

3. The interplay between method and canon in critical thinking is currently taking place in lively and diverse ways in many disciplines. Especially important for combining low-level and highlevel critical thinking skills, and combining teaching and research among 
the faculty, are works in different fields that claim to produce new readings of seminal texts, and forcefully raise questions about the relation between good critical practice and the methods we develop to account for and teach those practices. These works typically make theoretical claims for themselves, in addition to producing novel readings, and so in themselves exhibit the interplay between method and canon. The faculty of different fields can produce their own lists, but I would point to works like Hayden White, Metahistory, Cerald Bruns, Inventions, James White, The Legal Imagination, or Louise Dumont, From Mandeville to Marx.

These three lines of argument are incomplete. Not only does each of them need further development, but they all need connection to the accumulated wisdom grounded in practice at teaching critical thinking. While what I have been suggesting looks different from most of what gets called critical thinking these days, I think it would be foolish to ignore the growing body of practical experience in teaching critical thinking, especially experience generated by quite different conceptions of critical thinking. Critical thinking is a bit behind English composition in the amount of practical experience of teachers it can draw on, but teachers of critical thinking are rapidly accumulating successful and unsuccessful practices that are worth learning about, and which can be evaluated independent of the theories that supposedly generated them. No one can look at the textbooks, and discussions in Informal Logic, in the last few years without being impressed by the progress in the state of the art.

A desire to look at instances of successful teaching of critical thinking regardless of the theories from which they supposedly issue, though, creates a further obligation to look beyond courses with titles like Critical Thinking or Informal Logic to what happens in kinds of good teaching that range from composition courses to classes in law schools and business schools. I have always found it impossible to understand or even take seriously my sincere and unphilosophical colleagues when they say that their students don't know how to think, or that they teach thinking. There is a duty, though, to try to figure out what they mean.

Dr. Eugene Garver, Professor of Critical Thinking, Saint John's University, Collegeville, Minnesota 56321, U.S.A. 